\title{
A Tale of Two Experiments: Institutional innovations in Women's Group Farming in India
}

\author{
Document Version \\ Accepted author manuscript
}

Link to publication record in Manchester Research Explorer

\section{Citation for published version (APA):}

Agarwal, B. (2020). A Tale of Two Experiments: Institutional innovations in Women's Group Farming in India. Canadian Journal of Development Studies.

\section{Published in:}

Canadian Journal of Development Studies

\section{Citing this paper}

Please note that where the full-text provided on Manchester Research Explorer is the Author Accepted Manuscript or Proof version this may differ from the final Published version. If citing, it is advised that you check and use the publisher's definitive version.

\section{General rights}

Copyright and moral rights for the publications made accessible in the Research Explorer are retained by the authors and/or other copyright owners and it is a condition of accessing publications that users recognise and abide by the legal requirements associated with these rights.

\section{Takedown policy}

If you believe that this document breaches copyright please refer to the University of Manchester's Takedown Procedures [http://man.ac.uk/04Y6Bo] or contact uml.scholarlycommunications@manchester.ac.uk providing relevant details, so we can investigate your claim.

\section{OPEN ACCESS}




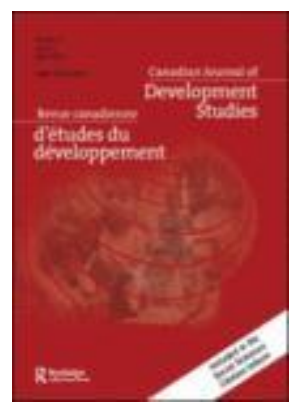

A Tale of Two Experiments:

Institutional innovations in Women's Group Farming in India

\begin{tabular}{|r|l|}
\hline Journal: & $\begin{array}{l}\text { Canadian Journal of Development Studies /Revue canadienne d'études du } \\
\text { développement }\end{array}$ \\
\hline Manuscript ID & CJDS-2020-0026.R1 \\
\hline Manuscript Type: & Original Article \\
\hline Keywords: & Institutional innovations, collectives, women's group farming, India \\
\hline
\end{tabular}

\section{SCHOLARONE \\ Manuscripts}




\title{
A TALE OF TWO EXPERIMENTS: Institutional innovations in Women's Group Farming in India
}

\section{Corresponding author}

\author{
Bina Agarwal \\ Professor of Development Economics and Environment \\ Global Development Institute, \\ School of Environment, Education and Development, \\ University of Manchester, UK \\ bina.india@gmail.com
}

\section{Acknowledgements:}

The discussion in this paper draws especially on interviews with key people involved in initiating or implementing the group farming projects in Telangana and Kerala (see Appendix A). I thank them all for their time and deep insights. I also thank the ESID project of the Global Development Institute, The University of Manchester, for financial support for this research, and the Institute of Economic Growth for logistical backing. I acknowledge the International Balzan Prize research funds awarded to me, which helped cover research assistance. And I am grateful to Sam Hickey, Kunal Sen, and the two anonymous reviewers of the journal for their helpful comments on an earlier draft.

\begin{abstract}
This paper traces the factors that shaped an unusual institutional innovation-group farming by women - in two states of India, Telangana and Kerala. Based on historical material and interviews with those who initiated and implemented these experiments, it examines how group farming for women's economic empowerment emerged as a significant programme in the 2000s, and its divergence from the previous four 'waves' of collective farming globally. Also, noting the substantial differences between the two states in programme implementation, such as in their governance structures, the size and social composition of groups, methods of scaling up, and forms of state support - the paper asks: what explains these differences and what was the thinking behind them? And how did the differences impinge on group performance and the potential for replication?
\end{abstract}

Keywords: institutional innovations, collectives, women's group farming, India

JEL codes: D02, P32, N55, O13 


\section{INTRODUCTION}

In the early 2000s, two states of India became the locus of an unusual institutional innovation-women's group farming. One was initiated by the state government of Kerala under its Kudumbshree programme for poverty eradication. The other was started in the state of Telangana by the central government and the United Nations Development Programme (UNDP), India, and implemented by a quasi-government NGO - the Andhra Pradesh Mahila Samatha Society (APMSS). Both experiments aimed at empowering poor women economically by providing them securer livelihoods.

These programmes departed radically from conventional approaches to rural women's empowerment, not only by focusing on farming but by shifting away from the usual preoccupation with individual family farming managed by male household heads, to group farms run entirely by women. Given the prevailing scepticism about collective farming arising from adverse perceptions about socialist collectivisation, as well as India's failed experiments with joint cultivation in the 1950s and '60s, this was a surprising shift. What explains it?

Moreover, while the two states converged in terms of promoting all-women group farms, they diverged substantially in the institutional structures through which the programmes were implemented, the size and composition of groups, their formalisation and autonomy, the nature of scaling up, and the forms and extent of state support and commitment. What explains these differences, and how did they impinge on the economic performance of the groups and their replicability?

This paper addresses both issues. First, tracing the antecedents of collective farming and its controversial history, it argues that the experiments in the 2000s stemmed from a very different origin to earlier attempts at group farming globally: they stemmed particularly from India's success with women's self-help groups and women's associations. Second, the paper shows that underlying the divergence in implementation between the two programmes were key differences in leadership and thinking about the form groups should take (their social composition, size, etc.), the organisational structure that was needed to give the groups autonomy and negotiating power, and the mechanisms for involving village women in 
participatory planning. In the background were also differences in the effectiveness of decentralised state governance. No existing study has addressed these issues to date.

The paper is divided into 7 sections. Section 2, which follows, provides a brief history of group farming globally. Section 3 outlines the ideas that led to the promotion of group farming in the two states, while Sections 4 and 5 trace the differences in the organisational structures that these states set in place for programme implementation, and the ideas that shaped those structures and group composition. These three Sections ( 3 to 5) are based on my in-depth interviews conducted over 2014-16 with key persons involved in shaping or implementing group farming in Telangana and Kerala (see Appendix A), supplemented, where possible, by an analysis of available reports and documents. Section 6 summarises my published results on the economic performance of women's group farms, based on my primary survey conducted in 2012-14 for 781 farm enterprises in three districts of Telangana, ${ }^{1}$ and 263 farm enterprises in two districts of Kerala. It also highlights how differences between the states in programme conceptualisation and implementation impinged on that performance, and on women's social and political empowerment. The concluding Section 7 reflects on the two experiments and the lessons they hold for replication elsewhere.

\section{THE IDEA OF GROUP FARMING: HISTORY AND PERCEPTIONS}

The idea of group farming is not new. Historically, we can identify at least five 'waves' of group farming (Table 1), with diverse origins, trajectories, and features. ${ }^{2}$

$<$ Insert Table 1 near here>

The first and best known wave is that of socialist collectivization, especially as undertaken in the USSR, Eastern Europe and China. The key features of these collective farms - created by forced pooling of peasant land by the state - was their non-voluntary nature, very large size (often involving thousands of hectares and farmers), centralized decision-making (with

\footnotetext{
${ }^{1}$ The sample districts were earlier part of undivided Andhra Pradesh, but now fall under Telangana state.

${ }^{2}$ I call them 'waves' since they occur within specific time spans and traverse more than one region or country.
} 
farmers having little voice), and compulsory deliveries of grain to the State. In time, it came to be widely recognized that the effects of this massive collectivization were highly detrimental to human welfare and agricultural productivity, especially in the USSR, ${ }^{3}$ and to a lesser degree in Eastern Europe which shifted course early, by abolishing compulsory deliveries and allowing households to keep small plots (see, Swain 1985, 1992; Berend 1990; and articles in Lordachi and Bauerkämper (eds.) 2014). In China, the effects varied regionally, depending on community ties, and ecological and demographic conditions (Li 2018).

In the 1960s and 1970s, however, the adverse effects of forced collectivisation were yet to be recognized, and there was a second wave of collective farming attempted in many non-socialist post-colonial countries of Latin America, Africa, Asia (including India), and the middle-east. ${ }^{4}$ Typically undertaken as part of agrarian reform, often influenced by ongoing programmes in socialist countries, some collectives covered a few farms, others entire villages (Agarwal 2010a). Although forming collectives was ostensibly voluntary, in practice State pressure was commonly applied, and the typically large farm size and socio-economic inequality within the group made participative decision making difficult. Groups formed among acquaintances, with minimal social differentiation, worked better (Borda 1971, Ruben and Leran 2005). Overall, however, few of these experiments survived.

In newly Independent India, there was considerable political support for cooperatives (Frankel, 1978), and in 1946, the Cooperative Planning Committee recommended the promotion of joint cultivation, influenced especially by Chinese policies (Ganguli 1953), as well as service cooperatives for credit, input purchase, machine use, etc. (Goyal 1966). ${ }^{5}$ However, large landowners, and significant political leaders resisted joint cultivation (Singh 1959), and efforts to bring large and small farmers together into one cooperative had little success. In time, most states shelved the idea (Frankel 1978). ${ }^{6}$ Marketing and credit

\footnotetext{
${ }^{3}$ For the USSR, see especially Robinson (1967) and Nove (1969), and for China, see Lin (1990), Putterman (1997) and Li (2018).

${ }^{4}$ See Borda (1971) for Latin America; Apthorpe (1972) for Africa; Goyal (1966) for India. Israel's Kibbutz also needs mention, although it was a unique form (Gavron 2002).

${ }^{5}$ See also, various issues of the Indian Journal of Agricultural Economics for the 1950s and 1960s.

${ }^{6}$ India promoted cooperative farming until its Third Five Year Plan (1961-66) but proposed no new schemes in its Fourth Plan (1969-1974) due to lack of progress.
} 
cooperatives continued, however, and new ones emerged (Mascarenhas 1988, Baviskar 1980), but these did not involve joint production.

While both the first and second waves of group farming - created largely by top-down State interventions - failed, the third and fourth waves, based on voluntarism, were largely successful, as in democratic Europe (especially France) and post-socialist countries. ${ }^{7}$ Under socialist decollectivisation, for instance, the plots restored to members of former collectives were typically too small for economic viability. Hence, in countries as diverse as Kyrgyzstan, Romania and East Germany, recipients voluntarily pooled their plots with those of family members or neighbours, to create larger units and invest in capital equipment. These group farms were found to be more productive than individual family farms. ${ }^{8}$

The fifth wave, however, took time to emerge. Given the disappointing outcomes of their 1950s-1960s experiments, planners and researchers in many developing countries came to see group farming as non-viable. This cloud of failure was not dispelled by the success of group farms in Europe or in the post-socialist transition economies, since rather little was known about them globally. What then explains the emergence of group farms on a notable scale in two states of India in the 2000s, and the departure from the standard male-headed groups to women-only groups in this fifth wave?

The answer lies in the considerable change that had occurred in our understanding of how collective action works by the early 2000s, when Telangana and Kerala launched their experiments. By then, substantial ground experience had been garnered in promoting collective institutions, especially in micro-finance and in governing common pool resources (see Ostrom 1990, on the latter). Among social scientists (especially economists) also, there was a growing recognition that cooperation could be built on trust and reciprocity among prior acquaintances (Baland and Platteau 1996, Agarwal 2010b). And a considerable consensus had emerged among development practitioners that group formation empowers the poor.

In India, the most important developments were the success of three types of groups:

\footnotetext{
${ }^{7}$ See Agarwal and Dorin (2019) for France, and Almas (2010) for Norway.

${ }^{8}$ See, Sabetes-Wheeler and Childress (2004), for Kyrgyzstan; Sabates-Wheeler (2002) for Romania; and Mathijs and Swinnen (2001) for East Germany.
} 
(a) Microcredit groups, in particular Self-Help groups (SHGs) formed by 10-20 self-selected persons of similar socio-economic backgrounds, who pool savings and rotate lending among members. In the mid-2000s, there were 2.6 million SHGs in India, 80-90\% constituted of women (Tankha 2012: 37,2). Many NGOs also saw SHGs as entry points to women's empowerment (NCAER 2008).

(b) Community groups governing common pool resources such as forests and water bodies. For instance, in 1990, the Indian government launched the Joint Forest Management Programme. By 2001, India had 84,000 community forestry groups. This significantly improved forest condition, with women's participation in governance further enhancing conservation outcomes (Agarwal 2010b).

(c) Groups delivering social programmes, such as for health and adult education. Of these, the government-initiated programme, Mahila Samakhya or education for women's empowerment, is an important example (Mahila Samakhya: A National Review, 2014), on which Telangana's group farms were later based.

The success of groups formed across diverse contexts made the group approach to programme delivery widely acceptable. But it did not automatically lead to group farming, which would have needed pooling private resources, mutual trust, and an equitable sharing of work, costs, and benefits among those cooperating. Hence, while prior experience in group functioning provided better ground for promoting joint cultivation in the 2000s than it did in the 1960s, group farming — which needs 'fully integrated cooperation'—was still something of a leap in the dark.

\section{CONTEMPORARY EXAMPLES: ORIGINS}

When Telangana and Kerala launched group farming, there was widespread acceptance within development policy and practice that development programmes needed to focus not only on disadvantaged households to improve human well-being, but also on women's empowerment and gender parity. This recognition began in the 1970s and spread transnationally through women's movements, civil society groups, academics, and international agencies (especially the United Nations). Similarly there was a focus on poverty 
alleviation and basic needs, with an expanding definition of poverty to include multidimensional measures.

Another paradigmatic shift related to the process of policy formulation, away from top-down expert-driven planning towards participatory planning in interaction with local communities. The idea of decentralised governance was also becoming popular. Although, in India, this was initiated soon after Independence from colonial rule in 1947, decentralisation became more firmly embedded after the 1992/93 constitutional amendments. These devolved greater financial powers to village councils and reserved one-third seats for women in the Panchayati Raj Institutions (PRIs) - India's three-tiered system of local self-government at the village, block and district levels. (The term panchayat is used here to mean village council, which can sometimes cover several villages.)

In addition, there was the noted increasing openness to using a group approach for programme delivery; a recognition within economic theory that collective action was possible under conducive conditions; and efforts at scaling up micro-initiatives by creating federations that connected individual groups. These ideational and institutional changes, in turn, informed the group farming programmes.

\subsection{The Telangana programme}

In the Telangana region of undivided Andhra Pradesh, the group farming project - termed Samatha Dharani (SD) — was initiated jointly by the UNDP and the Government of India (UNDP-GoI) in 2001, with guaranteed support for five years. The initiative was conceptualised as a 'project', without a detailed plan or state commitment on how it might continue after the project period. It was implemented in five districts of what is now Telangana state, through APMSS, which was established in 1993 to empower women via education under the GoI's Mahila Samakhya programme. For this purpose, APMSS created sanghas or women's collectives (one per village) in the districts where it worked. The village sanghas were then constituted into federations, scaled up to the district level (Jandhyala 2012). The all-women sanghas were composed of poor women belonging mostly to the socially disadvantaged Scheduled Castes (SCs). Group farming was built on this pre-existing sanga structure. 
Although there is little written on the ideas underlying the launch of this group farming project, my interviews with those involved in its initiation provide a picture. The idea emerged from several channels: prior examples of group farming in the region, experiments by village women, activist experience, academic research pointers, and UNDP's and APMSS's interest in focusing on agriculture — where most rural women workers are based.

To begin with, APMSS's senior staff was familiar with an important (if geographically limited) early experiment with women's group farming in the 1980s, undertaken by an NGO — the Deccan Development Society (DDS) — in Telangana's Medak district. Initially DDS worked only with male farmers, but when village women challenged DDS asking - 'Why don't you work with women?'- there was a shift (personal communication, P.V. Satheesh, Director, DDS). Over time, DDS moved entirely to groups of poor, low-caste women, who began to cultivate leased land in groups of 5 to 15 , sharing labour, inputs, and outputs equitably (Agarwal 2003). Some also took advantage of the state government's subsidized credit-cum-grant scheme under which low-caste women could purchase land in groups. They divided it individually but farmed it collectively. Knowledge of this prior experience influenced APMSS. As Kameshwari Jandhyala (State Programme Director of Mahila Samakhya) told me:

I was very familiar with DDS and some of our field staff had earlier worked in DDS.... We invited someone from DDS to tell us about women's land leasing efforts. This was the seed, and from 1996 onwards several ideas were afloat, and there was good cross fertilisation.

Second, in the early 1990s, some women's sanghas in Medak district leased in land to undertake group farming themselves, outside the purview of DDS (although probably influenced by its experience). However, this remained limited to a few groups until the UNDP project was launched (Kameshwari Jandhyala and P. Prasanthi, author's interviews).

Third, there appears to have been some impact of a discussion in my book (Agarwal 1994) on the need to promote women's group farming, given the large and increasing numbers of women dependent on agriculture for a livelihood. I had also shared these ideas in several 
public forums and with key individuals within UNDP and the government's agricultural extension department in Delhi. ${ }^{9}$

Fourth, a crucial bridging role, linking UNDP and APMSS, was played by UNDP staff, especially Kalyani Menon-Sen (then gender advisor to UNDP, India) and Neera Burra (then Assistant Resident Representatives, UNDP India). Menon-Sen was also an Executive Committee member of Mahila Samakhya for Uttar Pradesh state and participated in the national debates on what Mahila Samakhya should be doing for rural livelihoods. She was thus a key person when APMSS discussed the group farming project with UNDP in 1998-99. Others who worked on food security in Andhra Pradesh were also part of project conceptualisation. As Kameshwari Jandhyala put it: 'So you see, there was a history. Samata Dharani did not arrive suddenly out of the blue.'

At least in Telangana, therefore, group farming did not evolve from socialist ideas, nor were such ideas evoked by those who conceptualised the project within UNDP and the GoI, or by those implementing the project locally. Rather, economic activity was built on the sangha structure created earlier for women's social empowerment. This helped in so far as the women who took up group farming already knew each other, but building the programme on pre-existing sangas also meant that features such as large size and shared socio-economic disadvantage were not vetted to see if they were conducive to a collective economic enterprise. As P. Prasanthi noted (author's interview): 'The SHG model was good for economic programmes, but we were focusing on social empowerment, so numbers mattered.'

\subsection{The Kerala programme}

Kerala's group farming project also began in the 2000s, but, unlike Telangana, many of those who initiated it were influenced by left-wing socialist ideology, although they did not promote large collective farms. During 1987-89, under the Left Democratic Front (LDF) government led by the Communist Party of India, Marxist, for instance, Kerala tried group

\footnotetext{
${ }^{9}$ In particular, I spoke with Neera Burra (UNDP India) and gave a talk organised by UNDP India on October 18, 1996, elaborating on the need to promote group cultivation by women. I gave a similar talk at a workshop organised by the Ministry of Agriculture's agricultural extension department. Moreover, in the government's Ninth Five Year Plan formulated in 1996-1997, paras 2.1.130 to 2.1.134 were based entirely on my note to the Planning Commission, in which, in para 2.1.133, I specifically discuss joint cultivation by women (GoI 1997-2002).
} 
farming in 25 villages in its GALASA experiment (Group Approach for Locally Adapted and Sustainable Agriculture), as a follow-up to the state's land reform programme (Franke 1993; Devi 2006). Under it, farmers pooled land and cultivated jointly, but kept ownership rights to their plots. The groups saved on labour (Devi 2006) and their yields were estimated to be 30\% higher than before (Heller 1999: 146). However, the experiment petered out under the new coalition government. Hence, this early attempt was vulnerable to political change, unlike the current initiative of group farming that has survived several changes in government, not least due to its innovative organisational structure, discussed later.

Kerala's policy shifts evolved in two stages: first, Kudumbashree-the Kerala State Poverty Eradication Mission — was established by the state government in 1998; and second, group farming was adopted as a key component of poverty alleviation and rural women's empowerment. Kudumbashree was based on ideas emerging from three types of initiatives in the early 1990s: (i) a poverty reduction programme in the rural areas of Mallapuram (then Kerala's most backward district), which identified the poor through a nine-point multidimensional poverty index; ${ }^{10}$ (ii) an urban poverty alleviation and community based nutrition programme, launched by UNICEF in Alappuzha district for improving health and sanitation among women and children - they constituted neighbourhood groups to promote community participation; and (iii) the People's Plan Campaign through which the LDF government sought to involve people in the planning process - 'Planning Up' ${ }^{11}$ Also, $10 \%$ of the panchayat budget was designated for women's programmes. In other words, the idea of participative planning and women's inclusion were key elements of policy formulation.

The group farming initiative was thus based on an interlocking grid of ideas: decentralised management and decision-making with community participation; a multidimensional definition of poverty; mobilisation of grassroots thinking by the People's Plan Campaign; and a budgetary allocation in panchayats for a women's component plan. In

\footnotetext{
${ }^{10}$ Mr. T.K. Jose, who played a foundational role as Executive Director of Kudumbashree (1998-2006) during its formative years, was also District Collector in Mallapuram in the 1990s.

${ }^{11}$ The People's Plan Campaign, launched in 1996-97 by Kerala's LDF Government, was a massive exercise in decentralised planning, linked with the devolution of administrative and fiscal powers to the local government. The Campaign asked villagers to assess their priority needs; set up Task Forces in panchayats to prepare development projects; and constituted expert committees to prepare annual plans at the block and district levels based on these inputs, under the oversight of the Kerala State Planning Board (see also Isaac and Franke 2001).
} 
addition, there was a growing interest in reviving agriculture, and scaling up. These ideas were implemented through three parallel but interactive pillars of governance (detailed in section 4), one representing the Kudumbashree Mission (henceforth called the K.Mission), the second representing the community, and the third the local government. A special Task Force of three senior government officials played a key role here, as discussed later.

This organisational framework allowed ideas to permeate from below in the early years of the K.Mission. Examples began to surface from some districts of poor women farming collectively by jointly leasing land. Several village women also requested permission to cultivate fallow land. These demands fell on fertile ground, since those preparing the women's component plan were looking for viable economic activities for poor women. As Sarada Muraleedharan (Executive Director of the K.Mission, 2006-12) put it:

For the women's component plan we were looking for ways of enhancing women's livelihoods. We consulted the panchayats, but there was no clarity on what constituted 'women's projects'. Then grassroots stories of some women doing group farming showed a way forward.

Vijayananda (former Secretary, Local self-government, Government of Kerala) elaborates:

Kerala had a lot of land lying fallow.... and hiring labour was costly. The better-off who owned land did not think it was worthwhile cultivating it. Extremely poor women saw an opportunity here to cultivate the fallow land and approached the panchayat for help in acquiring it. They knew how to cultivate. They just needed help. They spontaneously set up informal farming groups.

These early examples of informal group farming through land leasing took more formal shape in 2010, when they began to be linked with credit under the Joint Liability Group (JLG) scheme of the National Bank for Agriculture and Rural Development (NABARD).

The participatory process of programme conceptualisation and implementation thus demonstrated an openness to learning from ground experimentation and ideas coming from village women, in contrast to the expert-driven process that typically shapes development programmes. 


\subsection{State and civil society as actors}

In both states, civil society and the government played important roles in programme formulation, but the nature, extent and continuity of State support received by Telangana's SDGs and Kerala's JLGs is a study in contrasts. And although both states promoted similar models of women leasing in land while also working on their family farms (if any), their organisational structures and implementation diverged widely.

At its height, the Telangana programme had 500 SDGs across five districts. Official support came essentially from the central government, while the state government's support was limited and inadequate. Each SDG received funds for a seed grant of Rs. 35,000, technical training in farming practices, and agricultural implements (some designed to suit women's needs), during the project's heyday. In addition, APMSS received funds to train women in accounting and financial literacy. The women were also taught organic farming through the state agricultural department, and taken on 'exposure visits' to other states to learn from farmers there (P. Prasanthi, author's interview; also APMSS Annual Reports). In some cases, crop demonstrations were organised in the women's fields.

In effective terms, however, the technical inputs and training provided by the state agricultural department were limited and lacked continuity. The SDGs were helped mainly by agricultural experts hired privately through UNDP funds, rather than by government officials (P. Prasanthi, author's interview). As Menon-Sen (2012:160) elaborates.

Ultimately APMSS hired women agricultural graduates. While the performance of these women was outstanding ... their presence cut off the possibilities of sensitising mainstream extension workers to the needs and priorities of women farmers. In the words of one such resource person, 'the seed of collaboration did not germinate at all.'

Despite setbacks, the SDGs continued to farm, overseen by the sangha federations and APMSS under its Mahila Samatha programme. But in 2016, even the latter programme was dissolved, and the future of the SDGs remains uncertain. 
In Kerala, state support was built into the programme through the K.Mission on a sustained basis. First, the JLG's were linked to subsidised credit via NABARD. (This was an all-India scheme, which the Telangana groups did not take advantage of.) Second, instead of giving them outright subsidies, an incentive system was instituted, with area incentives based on area cultivated and production incentives based on crop yields. Third, each CDS received Rs. 50,000 to buy farm equipment for setting up farmer facilitation centres. Fourth, women farmers were trained through agricultural universities in using machines, preparing organic pesticides, growing new fruits and vegetables, and other technical aspects. Some JLG members were also trained as 'Master Farmers' to respond to JLG needs. Fifth, during 200611, district-level meetings were held to discuss with the women what crops they would like to grow, and how they could specialise in niche crops such as pineapple and kadukki banana. As Ms. T.S. Seema (former Member of Parliament) explained to me:

When we started, many of the women had been agricultural workers, not farmers, and they lacked adequate knowledge of farming and farm management. Apart from Kudumbashree's training, older women farmers in the community (60-80 years of age) taught the younger ones.

Moreover, most of Kerala's JLG members are educated. This would have helped them absorb technical information better than in Telangana.

JLGs were also free to choose their crops based on market demand and profitability. In Telangana, however, APMSS sought to promote food security by asking SDGs to focus primarily on foodgrains. This reduced women's crop options, and in some cases it created tensions between APMSS and the SDGs who said they would have preferred to grow cotton if allowed to, given dryland farming conditions (Agarwal 2014).

\section{ORGANISATIONAL STRUCTURE FOR GOVERNANCE}

Perhaps the most important difference between the Telangana and Kerala initiatives was in the ideas that shaped their organisational structures, despite some broad commonalities. The commonalities lay in the mix of top-down and bottom-up leadership, and the substantial space given to village women themselves for programme development, even though the initial guidance came from the programme initiators. But the differences were also notable. 


\subsection{Telangana}

In Telangana, APMSS used the pre-existing sanghas from the Mahila Samatha programme to launch group farming, selecting villages with cohesive sanghas that had been functioning for many years. All sangha members could join the Samatha Dharani Group in their village (each village had one). The village level sanghas were represented in federations which were scaled up to the district level. These federations supported the SD programme, but the latter also absorbed the weaknesses of the pre-existing sangha structure. On its part, the UNDP-GoI project sought to mobilise local government support and technical help from the state agricultural department, but the latter's commitment to the project was neither automatic nor structurally assured.

In fact, there were tensions on the sharing of the UNDP funds between APMSS and the Andhra Pradesh agricultural department. For example, Kalyani Menon-Sen observed: 'The department questioned why the women (rather than the Department) were receiving most of the UNDP funds as well as the limelight' (author's interview). Nandini Prasad (Director of APMSS 1999-2003) added: 'We had a tough time. The state government saw it as an NGO programme, not as a government programme.' Moreover, once the UNDP funding ended in 2005, even the limited state support ceased.

\subsection{Kerala}

In contrast, Kerala's programme enjoyed substantial state commitment. Also, here the group farming project was implemented through an organisational structure which rested on three pillars. These pillars supported all forms of economic group enterprises under Kudumbashree, but became the backbone of group farming.

The first pillar was the K.Mission, created (as noted) in 1998 at the district and state levels to eradicate poverty through various economic enterprises, of which group farming was an important one. Government officials from relevant ministries were seconded to the Mission. The second and most important pillar was the Kudumbashree community network (or K.Network). This was constituted of neighbourhood groups (NHGs) at the village level, Area Development Societies (ADS) at the ward level, and Community Development 
Societies (CDS) at the panchayat level. Representatives from the NHGs were to be elected to the ADS, and representatives from the ADS were to be elected to the CDS. The third pillar was local self-government (the PRIs) whose members are elected through state-held elections, as elsewhere in India.

Each CDS (with its interlinked structure of ADS and NHGs) is registered as an autonomous charitable organisation to shield it from direct government intervention, while giving it negotiating power with the government on behalf of the community. The K.Network mediates with the PRIs and the K.Mission. The group farms (termed JLGs) are embedded in the NHGs and linked with the ADS and the CDS through the K.Network. Group farming via JLGs accounted for $12 \%$ of the K.Mission's total expenditure in 2011, making it financially the Mission's second most important programme (personal communication, Rahul Krishnan, K.Mission, Thiruvananthapuram, 2016).

This three pillar model is, I believe, unique in India. The K.Network-separate and autonomous of the PRIs - provides a mechanism for people's participation in development planning while also receiving government support through the K.Mission. Moreover, the geographic congruence of the CDS and the panchayats means that they can interface in planning.

Several enabling factors led to the creation of this three pillar organisational form. First, there was the fortuitous coming together of three key individuals as members of a Special Task Force set up by the Kerala government in 1997. All three had long experience in governance, were committed to inclusive development and people's participation, and had the power and mandate to implement their ideas. These were Isaac Thomas, a member of the State Planning Board and former academic economist with a strong commitment to decentralisation; Vijayanand, Secretary Local Self-Government; and P. Bakshi, Chairman and Managing Director of NABARD. Their recommendations led to the setting up of the State Poverty Eradication Mission in 1998, named the Kudumbashree Mission (the K.Mission). They also conceptualised the three pillar structure, drawing on a range of ideas: decentralised governance; participative planning; economic inclusion by gender and caste; and autonomy from political interference. And between them, they brought complementary skills to build the organisation. 
As Vijayananda told me:

Dr. Thomas Isaac brought political acceptability. I focused on development policy. Both of us were concerned about the power wielded by the local government and sought ways of creating governance institutions to tackle it. Dr. Bakshi focussed essentially on credit linkages and the economic roles of NHGs.

Other significant figures who helped shape and stabilise Kudumbashree in its formative stages were the K.Mission's executive directors, T.K. Jose and Sarada Muraleedhan, supported by a body of committed local staff. In other words, several important elements of the policy framing and implementation came together fortuitously.

\section{Autonomy}

The K.Network provided independence from the local government while also linking it with the local government, but not hierarchically. Making the K.Network autonomous of the panchayat was a masterstroke in organisation building.

As Vijayananda elaborated:

We wanted a structure free from the political party interference which could distort the identification of beneficiaries and the decisions made; it could become the agency of the panchayat thus undermining its natural creativity. Basically we thought that if local government starts meddling with the K.Network, it will be sucked into party politics. That would kill it. People will take positions and women will be backseat drivers.

We wanted the K.Network to work with the panchayats and not be under the panchayat. By being autonomous, the K.Network would become strong, organized. It could engage effectively with the local government to ensure better governance, but would not be bullied by the local government.

The local government was concerned that the women's groups would be getting a lot of money over which it had no oversight... We said: if you are giving money to the women's groups you can ask for accounts, but you can't interfere. 
Thomas Isaac, in particular, had done considerable thinking on democratic decentralisation and also published a book on it (Issac and Franke 2001). Although decentralisation and creating an autonomous network met with some resistance from elements of the government who felt power would go out of their hands, the ideas could not be dislodged. Sarada Muraleedharan notes: 'There was a debate and decentralisation won. It was a paradigm shift!'

SHGs vs. NHGs

Kudumbashree's second important organisational innovation was the use of NHGs as the base unit for bottom-up participation and planning. In most parts of India, self-help groups focused on thrift and credit, but in some states, such as Andhra Pradesh, SHGs went further to provide community linkages, and used the federation structure for scaling up (NCAER 2008). In Kerala, however, the SHG model itself was modified to form neighbourhood groups, NHGs. ${ }^{12}$

This adaptation had several advantages, as elaborated by those involved in establishing Kudumbashre. First, NHGs can go beyond saving-and-credit to become units of micro-planning which can feed into the final plans of the CDS and the panchayats. The plans prepared with grassroots ideas would be more relevant to local economic and ecological conditions. Second, NHGs can serve as sub-units of the gram sabhas (village council general bodies), which in Kerala are large and male-dominated, making it difficult for poor women to have a voice. An NHG of 10-20 members enables effective local participation. Third, NHGs ensure inclusiveness, since every household in a neighbourhood can have a representative member, and members who migrate on marriage can join the NHG where they move. The members know each other, and mixed-caste neighbourhoods help include low-caste and poor members as well. These neighbourhood groups, similar but not identical to SHGs, provide the bedrock of the first tier of community participation in Kerala. NHG members can start any group enterprise, including group farming. Each NHG can have several group farms.

The move to group farming after the formation of the K.Network was not immediate. In 1998, the K.Mission invited creative ideas for improving women's livelihoods. After

${ }^{12}$ On the characteristics of NHG members, see Kannan and Raveendran (2017). 
trying other types of microenterprises, often unsuccessfully, group farming was initiated. There was thus experimentation within the programme, and a two-way learning process

$$
\text { ****** }
$$

(Press! Please insert stars or bullets here since there is a break with the previous subsection.)

Overall, the Kerala experiment was part of the state government's larger commitment to inclusive development and women's empowerment, to be implemented by promoting group enterprises, of which group farming was the most significant. In Telangana, however, state government support was sought later for an idea that evolved from activist experience, grassroots experiments, and academic discourse, with an international organisation - the UNDP — as the lead funder. And the implementing organisational structures were vastly different.

\section{GROUP COMPOSITION}

Telangana and Kerala also differed notably in the principles guiding group composition their gender, heterogeneity, and size. Existing collective action theory pointed to the effectiveness of groups that were socio-economically homogenous and small in size (Olsen 1965), but subsequent theoretical developments, drawing on ground experience, recognised the potential benefits of heterogeneity in certain contexts (Marwell and Oliver 1988, Baland and Platteau 1996). The discussion on group homogeneity and collective action, however, was focused largely on household level differences (of class, caste, ethnicity, etc.) and not on individual level gender differences.

In prior non-socialist initiatives of group farming too, the family rather than individuals constituted the cooperating unit, and women remained largely embedded in supportive rather than leadership roles. In India, the family was represented by the male household head, except in female-headed households, and the 1960s cooperative farms were constituted of family units. Moreover, the collective farming experiments in the first four waves did not seek gender parity, either within socialist regimes or elsewhere. In USSR's collectivized farms, $85 \%$ of women employees relative to $66 \%$ of male employees worked in unskilled jobs, which carried lower pay than skilled jobs (Swain, 1985: 99). In China, again, 
women earned lower work points on the communes than men (Swain 1985). The shift to women-only group farming in this fifth wave was therefore a clear break from the past.

\subsection{Why only women?}

The idea of women-only group farms was propelled not only by an interest in women's empowerment, but also by the success of women's groups over men's groups in other contexts. For example, in micro-finance, women-only groups had better loan repayment records than men's groups, and the Grameen Bank which began with both women's and men's groups, ended up almost entirely with women-only groups. The SHG movement also ended up with almost 80-90\% women's groups. Moreover, many NGOs believe women's groups work better, as emphasised both by P. Prasanthi and Kameshwari Jandhyala (author's interviews). The latter noted:

I do think that women's groups work better. Whether it is the Mahila Samatha ${ }^{13}$ or the DDS, they are more willing to work in collectives. Their lives are so difficult, and I believe their life experience has shown that if they are together they can deal better with the issues that affect them.

In any case, since the Mahila Samatha programme was focused on women's empowerment and SDGs were based on the pre-existing sanghas, all-women groups were a natural corollary for setting up group farming in Telangana.

In Kerala, the NHGs were not initially confined to women, but it was soon realised that rather few women attended gram sabhas due to restrictive social norms, while the SHG movement contained mostly women. Hence, to ensure women's inclusion, the K.Network decided to focus specifically on women, as Thomas Isaac and Vijayananda explained (author's interviews):

With NHGs constituted of both men and women we found that the meetings were not regular. In contrast, SHG women met once a week for economic transactions. Moreover

\footnotetext{
${ }^{13}$ This was the nomenclature of the Mahila Samkhya programme in Andhra Pradesh.
} 
women needed a space to sit for 3-4 hours. So we decided to go for women-only NHGs where women could identify their priorities, and make suggestions to the gram sabha. (Thomas Isaac)

The move to all-women NHGs was based on our understanding that women tend to recognize the implications of poverty better. They understand savings better. They are more careful with thrift ... And specially in Kerala, the women's groups tend to function more harmoniously than men's groups, which get divided by politics. Men tend to come under diverse political influences. (Vijayananda)

Sarada Muraleedharan adds another dimension: 'Initially NHGs had men talking and women serving the tea. So we mooted the idea of women-only NHGs.' The group farms were constituted by women who were NHG members or belonged to families with an NHG member.

\subsection{Heterogeneity}

On the question of group heterogeneity, again, Telangana and Kerala diverged. In my sample survey, $86 \%$ of Telangana's SD members belonged to SC/ST communities with virtually no upper-caste women (Agarwal 2020). The SDG composition reflected APMSS's emphasis on constituting sanghas of poor women from SC backgrounds. In Kerala, by contrast, $14 \%$ of the JLG members in my sample were upper-caste and only $9 \%$ were SC/ST, the rest being Other Backward Castes. (Overall also, only $9.1 \%$ of Kerala's population is SC, compared to $15.5 \%$ of Telangana's population, where another $9 \%$ is Scheduled Tribe.)

In their decisions on group composition, neither state followed collective action theory, which would have supported socially homogenous groups of small size. Rather they were driven by specific aims. APMSS rooted for the lowest caste and most disadvantaged women when they formed sanghas (prior to group farming), since social empowerment was their primary goal. As Kameshwari Jandhyala explained to me:

In the districts where we are working, the marginalised and excluded are the dalits, and if you want to promote leadership and more equal participation in local community affairs and governance, you need to start with them. You can't have mixed groups. 
Our view was that multiple groups of poor women organised into mixed caste SHGS would not go far, since leadership would always go to upper-caste women. In the sangha model, we wanted to create one platform for dalit or marginalised women, but disadvantaged Muslim women were also included in districts which had them.

Kerala proactively deviated from this model and encouraged some heterogeneity, partly to promote inclusiveness, since the groups were embedded in neighbourhoods which in Kerala are less segregated by caste and religion than in Telangana, and partly for ensuring leadership. Hence Kerala's JLGs were more caste and class diverse (although within limits, since the majority were still backward caste and poor).

According to Thomas Isaac (author's interview):

Local women's leadership does not come from the poorest of the poor. It comes from those who have some education and are just above the poverty line. In Kerala, poverty did not decline solely by the actions of the poor, but the joint actions of the poor and less poor. So we were strictly against homogeneity based only on the poor. Anyway, Kerala farmers are small, normally owning 35 cents or so of land.

Some did argue that the better-off will capture the organisation. So we stipulated that NHG meetings where tea is served would rotate across households-poor and less poor, upper and lower caste. Such practices help ensure that no section captures the group.

Ms. T. N. Seema (former Member of Parliament) recounts a case where some uppercaste women were not attending meetings held at the homes of SC members. 'We asked two of them: 'How can you be part of Kudumbashree without going to an SC member's house? Are you in or out?' They returned in two days to say they would go to the SC woman's house. ${ }^{14}$ According to T. K. Jose (Executive Director of K.Mission, 1998-2006): 'Caste is not a big problem for Kerala. SCs in Kerala are not living in their own hamlets'.

\footnotetext{
${ }^{14}$ The Self Employed Women's Association (SEWA) similarly found that within a year of forming groups, poor women overcame their caste-related discord (personal communication, Renana Jhabvala, Chairperson SEWA Bharat).
} 
Valsala Kumari (Executive Director of K.Mission, 2012-16) adds: 'Economic incentives also help break caste barriers and get people to cooperate.'

When Kudumbashree began, its membership was restricted to poor families, but later it became more economically heterogeneous:

Initially Kudumbashree was oriented to be a poverty eradication programme through women's empowerment. Rather few members owned cultivable land. But around 20072008 , the orientation was changed from being mainly a poverty reduction programme to a women's empowerment programme. So women did not need to come only from very poor families. (T.K. Jose, author's interview).

Mr. N. Jagajeevan, who was deeply involved in the People's Plan Campaign, also emphasises that heterogeneity is advantageous, 'because then NHGs and JLGs have more social connections, are better accepted by different segments of society, and provide an economic cushion to the group'.

\subsection{Group size}

Telangana and Kerala also differed on appropriate group size. In Telangana, since all sangha women could join, most SDGs were large, ranging from 10 to 54 members, the average size being 25. And since there was one sangha per village there was only one SDG per village. According to P. Prasanthi (author's interview):

The APMSS understanding is that a large group can influence the panchayat and local policy better than a small group, so we went for one sangha per village. Also the confidence of SC/ST women tends to be low, so we thought a bigger group would strengthen them and give them voice in the community.

We continued with this idea for the livelihoods programme... At that time nobody thought a large size would be a constraint. At times we did feel that more than 30 was perhaps too large and 20 or so would be better, but we did not think of groups as small as 6-7 members. 
In Kerala, however, JLGs are smaller, limited both by economic considerations and NABARD specifications of 4-10 members. It was also recognised that larger groups would reduce per capita returns. In my sample, JLGs had 3-12 members, the average being 6 .

In short, a variety of ideas and assumptions underlay the differences in organisational structures and group composition between the two states. In Kerala these issues were more carefully thought through and debated than in Telangana, where group size was determined by prior sangha size, and homogeneity was dictated by considerations of social empowerment rather than economic effectiveness.

\section{IMPLICATIONS}

The differences between Telangana and Kerala in their organisational structures, group composition, and State support had implications for the economic performance of group farms, as judged by their productivity and profits, relative to individual farms in the sampled districts of each state. Effectively the comparison was between all-women groups cultivating leased in land and individual family farms, $95 \%$ of which were male managed in both states and used mostly owned land. The economic results are important not only for judging the potential success of group farming in improving livelihoods, but also because they are likely to influence policymakers about the desirability of replicating group farming elsewhere.

\subsection{Economic effects}

The detailed results are given in my 2018 paper (Agarwal 2018) and summarised here. In Kerala, the group farms did significantly better than individual farms: their annual average value of output was 1.8 times greater, and annual average net returns per farm (calculated by subtracting all paid out costs from the annual value of output) were 5 times higher. They did especially well in bananas, entering into contracts in niche markets for special varieties. In Telangana, however, group farms performed much less well than individual farms in their average annual productivity, although they were broadly on par in their annual net returns per farm, since they saved on purchased inputs, especially hired labour. 
Notably, in both states, group farms performed much better with commercial crops than traditional foodgrains such as rice, in which individual male farmers had an advantage, since they owned good quality land and had long experience in rice cultivation. Since SDGs focused mainly on cereals due to APMSS' strong emphasis on foodgrains, the economic returns of most SDGs were adversely affected by crop choice.

Moreover, since Telangana's SDGs were constituted largely of poor SC women, they faced difficulties in leasing land. Upper-caste landowners were less willing to lease to SDGs, and the geographic distance of SC communities from upper-caste settlements also reduced SDG access to land near their homesteads (Agarwal 2020). On this count, APMSS could provide them rather little support. By contrast, the caste heterogeneity of Kerala's JLGs gave them a wider social circle to draw upon. They also sometimes received informal support from the K.Network for accessing land. Hence $71 \%$ of Telangana's SDGs were cultivating land leased only from within the group, while in Kerala this percentage was only 13; the rest leased land from other landlords, wholly or partly (Agarwal 2020).

Overall, Telangana's groups faced a range of constraints, including inadequate state support (technical and financial); groups constituted almost entirely of SC women, which limited their reach for accessing land, inputs, and technical information; large group size which made coordination more difficult and reduced per capita gains; and the catalysing NGO's emphasis on foodgrains. In contrast, Kerala's group farms enjoyed support from the local government and the K.Network. They had bank linkages for subsidised credit; financial incentives for high performing groups; freedom to choose their crops, including commercially profitable ones; small group size; high literacy; and socio-economic heterogeneity which broadened their social networks and economic reach in accessing land, inputs and markets. Some Kerala groups even used their profits to purchase land collectively. ${ }^{15}$

In 2015, when I asked P. Prasanthi what she thought Telangana should have done in hindsight, she observed:

\footnotetext{
${ }^{15}$ This is notable, given that only a very small percentage of women in India own land individually, even allowing for the somewhat better record of south Indian states in this regard (Agarwal, Anthwal and Mahesh 2020).
} 
We should have trained some sanga women in agricultural practices to constitute a technical support team for the SDGs. We should also have tied up with the government's agricultural department for continuous support to sanghas and asked them to place a mandal level team to back the SDGs. The government's ATMA programme which had a particular emphasis on women farmers could also have been better used. ${ }^{16}$ Another aspect was water supply - we did not look at the potential for rainwater harvesting. Moreover, the groups were too large. We should have limited the numbers and formed two groups per village for viability.

Nevertheless, both states broadened women's economic, social and political horizons. Women in both states emphasized that group farming greatly improved their ability to use economic institutions such as banks, agricultural departments, and markets for land and inputs. They also reported improved knowledge of new cultivation practices, which they used for their family farms as well (Agarwal 2018, 2020).

\subsection{Social and Political implications}

Socially, too, in both states, women reported being more respected by their communities and families (Agarwal 2020). This is especially important in Telangana where the women face substantial caste-related disadvantage. Also, for social empowerment, large groups can be more effective. Social cohesion and the causes they took up (such as domestic violence and child marriage) had a strong uplifting effect for sangha women in Telangana, whereas Kerala's JLGs were not especially active on this front.

In addition, in both states group members stood for local panchayat elections and many won. In Kerala this effect is stronger, since every political party is now reported to seek candidates from the K.Network for panchayat elections (author's interview with Jagajeevan). This increases JLG women's political clout, and strengthens the synergy between the

\footnotetext{
${ }^{16}$ ATMA is the Agricultural Technology Management Agency supported by the central government in seven Indian states, including Andhra Pradesh. It is responsible for all technology dissemination to farmers at the district level, and expected to pay particular attention to women farmers, and use a group approach.
} 
K.Network and the panchayats, as was anticipated by those designing Kudumbashree's governance structure.

\subsection{Sustainability}

In Telangana, the UNDP project ended in 2005; and with the dissolution of the Mahila Samatha programme in 2016 APMSS' support to SDGs also petered out. The programme suffered not only from the very short-term commitment of the central government and UNDP, but also from political changes, including the bifurcation of Andhra Pradesh in June 2014

In contrast, Kudumbashree's organisational framework has provided a foundation for sustainability. In particular, the creation of an autonomous K.Network, with formal links with the K.Mission, has enabled the programme to weather political changes. Indeed, since the mid-1990s we see a veritable see-saw between the LDF government which dominated in 1996-2001 and 2006-2011 and the UDF (United Democratic Front) government which dominated in 2001-06 and 2011-16. In 2012, Kudumbashree faced a political challenge under the UDF, when the then Minister for Rural Development announced plans to launch the National Rural Livelihoods Mission in Kerala through all 'competent NGOs', remarking that the K.Mission was 'not competent enough to implement the national scheme'. This move to replace Kudumbashree by other agencies provoked protests by activists, researchers and many ordinary citizens of Kerala, leading to the proposal being shelved (The Hindu, 2012). The protests underlined the extent to which Kudumbashree was able to garner support from a wide section of the elite and middle classes, not least due to the reach of its programmes, including urban sanitation and waste management (Kumar 2014).

\section{REFLECTIONS AND REPLICATION}

\subsection{Reflections}

In sharp contrast to socialist collectivisation which paid rather little attention to the hardships faced by small peasants due to the collectivisation drive, the fifth wave of group farming carved out its own model, aimed at eradicating poverty and empowering poor women. For this it drew particularly on local experience with SHGs and women's collectives. 
The application of this experience, however, led to divergent approaches on the ground. Hence, while both Kerala and Telangana developed the idea of group farming through interactions between experts and activists, the type of institutional transformation attempted by each differed in many respects, and affected the functioning and sustainability of the two programmes. In particular, there were differences in leadership, institutional structure, and group composition.

Leadership played a key role in shaping the programmes. The APMSS leaders were almost all women, while in Kerala they were predominantly male, but the difference in their degree of leverage was due less to their gender and more to the official positions they occupied. The Telangana leaders came from civil society with deep commitment and substantial experience especially in women's social empowerment. Kerala's programme leaders had significant administrative experience and authority, and brought acumen that covered the political, bureaucratic, and financial spheres. Moreover, the initial executive Directors of the K.Mission were not only from the government but also had prior experience in developing innovative community programmes and were deeply committed to the idea of Kudumbashree.

Although leaders in both states sought to create institutions that could serve as a bulwark for the women's groups against local power centres, the institutions created were not equally effective. Both built federated structures, but APMSS's sangha federations depended more on numbers for dealing with panchayats and the upper-caste rich, and lacked structured links with PRIs or the bureaucracy. In contrast, the K.Network could engage with panchayats on an equal basis and also draw on government support.

Moreover, APMSS remained embedded in a framework created for social empowerment (large size, socio-economic homogeneity of the groups, etc.), and assumed this would also prove effective for economic empowerment, while Kudumbashree promoted economic empowerment as a means to social empowerment. It went for small group size, a degree of socio-economic heterogeneity, and crops with growing markets.

There were differences too in expansion and scaling up. The Telangana programme remained confined to its initial five districts, and when UNDP-GoI involvement ended many 
groups dissolved. By 2011 only three districts had substantial numbers of active SDGs, although even this was laudable, given limited state support. By contrast, in Kerala, Kudumbashree continues to grow in numbers and reach, and now covers all districts of the state. Although some groups have become inactive, new groups have emerged. Moreover, since Kerala's NHGs are also units of micro-planning, they help sustain a bottom-up process of identifying problems and finding solutions.

The above factors played out differently in the gains of group farming in the two states. Economically, Kerala's group farms have done strikingly better than individual farms. The sustained nature of state support in capacity building, bank linkages, incentives, etc., have enabled the women to overcome gender inequalities in the production process in greater extent than in Telangana. Socially, however, the Telangana groups-which faced multiple layers of disadvantage (caste, class and gender) - have traversed longer distances than the Kerala groups. Politically, although women in both states have gained, the institutional structure created by Kudumbashree has paid greater dividends in outreach and bargaining power.

\subsection{Replication}

Is Kerala special or is the programme replicable elsewhere? Kerala does have some specific advantages, such as its 1960s-70s redistributive land reform which greatly reduced economic and social inequality (Frank and Chasin 2000); high female literacy; and a matrilineal system covering some $20-30 \%$ of households. This likely accounts for $41 \%$ of the sample JLG women owning some land (compared with $19 \%$ of SDG women); although patriarchal attitudes also persist (Eapen and Kodath 2002).

At the same time, many aspects of the Kudumbashree model are potentially adaptable, (and important to adapt for effectiveness). The most key is its three pillar approach to governance in which communities have their own body of representation, independent of the panchayats. This structure has helped the Kudumbashree programme to sustain for almost two decades, despite successive changes in government. Something like the K.Network, constituted of formally registered community development societies with democratic elections, could be created by other states, using SHG federations creatively. 
Similarly, the lessons Kerala offers on the size and social composition of groups, and the importance of giving groups autonomy in crop choice, can be applied elsewhere. Perhaps less easy, but not impossible to replicate, is the formalisation of government commitment towards a state-level programme of poverty alleviation and livelihood transformation, using a group approach.

In any case, as the results of these experiments percolate, they will help create a more optimistic narrative about group farming to overcome the historical negatives. Kerala's experience, in particular, provides considerable scope for optimism on this count. In fact, successful experiments of group farming have emerged in Eastern India and Nepal in recent years, albeit on a small scale (Sugden et al. 2020). They have taken cues from Kerala and Telangana, but also innovated to create groups adapted to the local context.

\section{REFERENCES}

Agarwal, B. (2003). 'Gender and land rights revisited: Exploring new prospects via the State, family and market', Journal of Agrarian Change, 3 (1\&2): 184-224.

(2010a). 'Rethinking agricultural production collectivities', Economic and Political Weekly, 55(9): 64-78.

(2010b). Gender and green governance. Oxford: Oxford University Press.

(2014). 'Food sovereignty, food security and democratic choice', Journal of Peasant Studies, 41:6, 1247-1268

(2018). 'Can group farms outperform individual family farms? Empirical insights from India', World Development, 108: 57-73.

(2020). 'Does group farming empower women? Lessons from India's experiments', Journal of Peasant Studies, 47(4).

Agarwal, B., Anthwal, P. and Mahesh, M. (2020). 'Which women own land in India? Between divergent data sets, measures and laws', GDI Working paper 2020-43, University of Manchester, UK.

Agarwal, B. and Dorin, B. (2019). 'Group farming in France: Why are some regions more conducive to cooperative ventures than others?' Environment and Planning A, 51(3) 781804.

Almas R. (2010). 'I have seen the future and it works: How joint farming may solve contradictions between technological level and farm structure in Norwegian dairy 
production'. In: Bonanno, A.B., Jussauma, R., Kawamura, Y., Shucksmith, M. (eds). From Community to Consumption. Bingley: Emerald Group Publishing Limited, pp.3-16.

APMSS. (2005). Annual report 2004-05. Andhra Pradesh Mahila Samatha Society, Hyderabad.

Apthorpe, R. (1972). Rural Cooperatives and Planned Change in Africa: An Analytical Overview. Geneva: UNRISD.

Baland, J. M., and Platteau, J. P. (1996). Halting degradation of natural resources: Is there a role for rural communities? Oxford: Clarendon Press.

Borda, O. F. (1971). Cooperatives and rural development in Latin America. Geneva, UNRISD.

Burra, N. (2004). 'Empowering women for household food security: UNDP's experience', United Nations Development Programme, Delhi.

Devi, S. (2006). Employment of labour and rural development. New Delhi: Sarup \& Sons.

Eapen, M., and Kodath, P. (2002). 'Family structure, women's education and work: Reexamining the high status of women in Kerala', Working Paper 341, Centre for Development Studies, Thiruvananthapuram, Kerala, India.

Franke, R.W. (1996). Life is a little better: Redistribution as a development strategy in Nadur village, Kerala. New Delhi: Promilla \& Co. Publishers.

Frankel, F. (1978). India's political economy 1947-1977: The gradual revolution, Princeton University Press.

Ganguli, B.N. (1953). 'Land reform in a new China', Occasional paper No. 9, Delhi: Ranjit Printers and publishers.

Gavron, D. (2000). The kibbutz: Awakening from utopia. Lanham: Rowman \& Littlefield.

GoI. (1997- 2002). The Ninth Five Year Plan, Vol. II. Planning Commission of India, Government of India.

Goyal, S.K. (1966). Cooperative farming in India. Bombay: Asia Publishing House.

Heller, P. (1999). The Labour of Development: Workers and the Transformations of Capitalism in Kerala, India. Ithaca and London: Cornell University Press.

The Hindu. (2012). 'Kudumbasree not competent to implement NRLM', Thiruvananthapuram edition, 29 February.

Howes, M and R. Chambers. (1979). Indigenous technical knowledge: Analysis, implications and issues, IDS Bulletin, 10 (2). 
Jandhyala, K. (2012). 'From sanghas to federations'. In Ramachandaran , V. and Jandhyala, K. (eds.). Cartographies of Empowerment: The Mahila Samakhya Story. Delhi: Zubaan Books, pp. 105-138.

Kannan, K. P., \& Raveendran, G. (2017). Poverty, women and capability: A study of the impact of Kerala's Kudumbashree system on its members and their families. Report.

Thiruvananthapuram: Laurie Baker Centre for Habitat Studies.

Kumar, A.N. (2014). Role of Kudumbasree in waste management, $\mathrm{PhD}$ thesis, Mahatma Gandhi University. http://shodhganga.inflibnet.ac.in/handle/10603/19608

Lin, J. Y. (1990). 'Collectivisation and China's agricultural crisis in 1959-1961', Journal of Political Economy, 98(6): 1228-52.

Li, H. (2018). Institutions and work incentives in collective farming in Maoist China. Journal of Agrarian Change, 18, 67-86.

Lordachi, C. and Bauerkämper, A. (eds.). (2014). The Collectivization of Agriculture in Communist Eastern Europe: Comparison and Entanglements. Budapest and New York: Central European University Press.

Marwell, G. and Oliver, P.E. (1988). 'Social Networks and Collective Action: A Theory of the Critical Mass, III', American Journal of Sociology, 94(3): 224-53.

Mascarenhas, R.C. (1988). A Strategy for Rural Development: Dairy Cooperatives in India. New Delhi: Sage publications.

Mathijs, E and J F M Swinnen. (2001). 'Production Organisation and Efficiency during Transition: An Empirical Analysis of East German Agriculture', The Review of Economics and Statistics, 83(1): 100-07.

Menon-Sen, K. (2012). 'Songs of Change in a Minor Key?' In V. Ramachandaran and K. Jandhyala (eds.). Cartographies of Empowerment: The Mahila Samakhya Story, Delhi: Zubaan Books, pp. 139-170.

NCAER. (2008). 'Impact and sustainability of SHG bank linkage programme'. New Delhi: National Council of Applied Economic Research.

Nove, A. (1969). An economic history of the USSR. London: Allen Lane, The Penguin Press.

Olson, M. (1965). The logic of collective action: Public goods and the theory of groups. Cambridge MA: Harvard University Press.

Ostrom, E. (1990). Governing the commons (Cambridge: Cambridge University Press).

Putterman, L. (1997). 'China's Collectivisation Puzzle: A New Resolution', Journal of Development Studies, 33(6): 741-63. 
Robinson, G. T. (1967). Rural Russia under the Old Regime: A History of the LandlordPeasant World and a Prologue to the Peasant Revolution of 1917, The Macmillan Company, New York.

Sabates-Wheeler, R. (2002). 'Farm strategy, self-selection and productivity: Can small farming groups offer production benefits to farmers in Post-Socialist Romania', World Development, 30 (10): 1737-53.

Sabates-Wheeler, R and Childress, M D. (2004). 'Asset-pooling in uncertain times: Implications of small-group farming for agricultural restructuring in the Kyrgyz Republic,' IDS Working Paper 239, Institute of Development Studies, University of Sussex.

Singh, C. (1959). Joint Farming X-rayed. The Problem and its Solution, Bombay: Bhartiya Vidya Bhavan, Chaupatty.

Sudgen,F., Agarwal, B., Leder, S., Saikia, P., Raut, M., Kumar, A., Ray D. (2020). Experiments in Farmer Collectives in Eastern India and Nepal, Process, Benefits and Challenges, Journal of Agrarian Change, forthcoming.

Swain, N. (1985). Collective Farms Which Work? Cambridge: Cambridge University Press. Tankha, A. (2012). Banking on Self-Help Groups: Twenty Years On. Delhi: Sage Publishers. Thomas, I. and Franke, R. W. (2001). Local democracy and development: People's Campaign for decentralised planning in Kerala. Delhi: LeftWord. 
Table 1: Global Waves of Group Farming: From forced collectivisation to voluntary cooperation

\begin{tabular}{|c|c|c|c|c|}
\hline $\begin{array}{l}\text { Waves of } \\
\text { group } \\
\text { farming }\end{array}$ & Motivation & $\begin{array}{l}\text { Period of } \\
\text { initiation }\end{array}$ & Countries & Type \\
\hline \multirow[t]{2}{*}{ First wave } & \multirow[t]{2}{*}{ Socialism } & $1920 \mathrm{~s}$ & USSR (whole country) & $\begin{array}{l}\text { Top-down, coercive, } \\
\text { vast collective farms, } \\
\text { non-participative }\end{array}$ \\
\hline & & $\begin{array}{l}1940- \\
1950 \mathrm{~s}\end{array}$ & $\begin{array}{l}\text { Eastern Europe, China } \\
\text { (whole countries) }\end{array}$ & $\begin{array}{l}\text { Top-down, coercive, } \\
\text { large collective } \\
\text { farms, non- } \\
\text { participative }\end{array}$ \\
\hline Second wave & $\begin{array}{l}\text { Non-socialist, } \\
\text { agrarian reform }\end{array}$ & $\begin{array}{l}\text { 1950s, } \\
1960 \mathrm{~s}\end{array}$ & $\begin{array}{l}\text { Asia, Africa, Latin } \\
\text { America, and the Middle } \\
\text { East (some countries) }\end{array}$ & $\begin{array}{l}\text { Semi-voluntary to } \\
\text { coercive, ranging } \\
\text { from small groups } \\
\text { farms to entire } \\
\text { villages }\end{array}$ \\
\hline Third wave & $\begin{array}{l}\text { Non-socialist, } \\
\text { community led }\end{array}$ & $\begin{array}{l}1960 \mathrm{~s}, \\
1970 \mathrm{~s}\end{array}$ & $\begin{array}{l}\text { France (across the } \\
\text { country) } \\
\text { Norway (some regions) }\end{array}$ & $\begin{array}{l}\text { Voluntary, medium } \\
\text { sized group farms }\end{array}$ \\
\hline Fourth wave & $\begin{array}{l}\text { Post-socialist, } \\
\text { decollectivisation }\end{array}$ & $1990 \mathrm{~s}$ & $\begin{array}{l}\text { Russia, Eastern Europe, } \\
\text { Central Asia }\end{array}$ & $\begin{array}{l}\text { Voluntary, small to } \\
\text { medium sized group } \\
\text { farms }\end{array}$ \\
\hline \multirow[t]{3}{*}{ Fifth wave } & $\begin{array}{l}\text { Empowering } \\
\text { farmers }\end{array}$ & $\begin{array}{l}\text { Late- } \\
1980 \mathrm{~s}\end{array}$ & $\begin{array}{l}\text { Andhra Pradesh: Deccan } \\
\text { Development Society (a } \\
\text { few villages) } \\
\text { Kerala: GALASA (a few } \\
\text { villages). }\end{array}$ & $\begin{array}{l}\text { Voluntary, small } \\
\text { group farms }\end{array}$ \\
\hline & $\begin{array}{l}\text { Empowering } \\
\text { women }\end{array}$ & $\begin{array}{l}\text { Late- } \\
1990 \mathrm{~s}, \\
2000 \mathrm{~s} \\
\text { ongoing }\end{array}$ & $\begin{array}{l}\text { Telangana region of } \\
\text { Andhra Pradesh (some } \\
\text { districts): APMSS } \\
\text { Kerala: Kudumbashree } \\
\text { (the whole state) }\end{array}$ & $\begin{array}{l}\text { Voluntary, small } \\
\text { group farms }\end{array}$ \\
\hline & $\begin{array}{l}\text { Empowering } \\
\text { marginal farmers }\end{array}$ & $\begin{array}{l}2015 \\
\text { onwards }\end{array}$ & $\begin{array}{l}\text { Nepal, North Bihar, } \\
\text { West Bengal }\end{array}$ & $\begin{array}{l}\text { Voluntary, small } \\
\text { group farms }\end{array}$ \\
\hline
\end{tabular}




\section{Appendix A: Persons interviewed}

\begin{tabular}{|c|c|}
\hline $\begin{array}{l}\text { State and person } \\
\text { interviewed }\end{array}$ & Designation of person interviewed \\
\hline \multicolumn{2}{|l|}{ TELANGANA } \\
\hline Ms. Kameshwari Jandhyala & $\begin{array}{l}\text { Project Director, APMSS, 1992-1996 } \\
\text { National consultant for Mahila Samakhya, 1996-2000, 2003-2006 }\end{array}$ \\
\hline Ms. Nandini Prasad & Project Director, APMSS, 1999-2003 \\
\hline Ms. P. Prasanthi & $\begin{array}{l}\text { State resource person for Mahila Samakya, 2000-2004; State Project } \\
\text { Director APMSS, 2004-2016 }\end{array}$ \\
\hline Ms. Kalyani Menon-Sen & Gender Advisor to UNDP, India, during project period, 1997-2004. \\
\hline Ms. Neera Burra & $\begin{array}{l}\text { UNDP, India, 1995-2007: Assistant Resident Representative for } 10 \\
\text { years. }\end{array}$ \\
\hline \multicolumn{2}{|l|}{ KERALA } \\
\hline Dr. Isaac Thomas & $\begin{array}{l}\text { Member, State Planning Board during Kudumbashree's initiation. } \\
\text { Member of the three person Special Task Force set up in } 1997 \text { for } \\
\text { identifying pathways to poverty eradication in Kerala. The Task } \\
\text { Force conceptualised and initiated the establishment of } \\
\text { Kudumbashree's institutional structure. }\end{array}$ \\
\hline Mr. S.M. Vijayananda & $\begin{array}{l}\text { Secretary, local self-government, Govt. of Kerala, 1996-2001, 2004- } \\
2011 . \\
\text { Member of the } 1997 \text { Special Task Force mentioned above. } \\
\text { Chairman, Executive Committee, Kudumbashree, 1998-2001, 2004- } \\
2011\end{array}$ \\
\hline Dr. P. Bakshi & $\begin{array}{l}\text { General Manager, NABARD, 1994-1999. } \\
\text { Member of the } 1997 \text { Special Task Force mentioned above. }\end{array}$ \\
\hline Mr. T.K. Jose & Executive Director, Kudumbashree Mission, 1998-2006 ${ }^{\mathrm{a}}$ \\
\hline $\begin{array}{l}\text { Ms. Sarada Muralidharan, } \\
\text { IAS }\end{array}$ & Executive Director, Kudumbashree Mission, 2006-2012 \\
\hline Dr. K.B. Valsala Kumari & Executive Director, Kudumbashree Mission, 2012-2016 \\
\hline Mr. N. Jagajeevan & $\begin{array}{l}\text { Associated with Kudumbashree since 1998. Worked in expert cell of } \\
\text { State Planning Board and incharge of training in the People's Plan } \\
\text { Campaign, 1996-2001 }\end{array}$ \\
\hline Ms. T.N. Seema & $\begin{array}{l}\text { Member Rajya Sabha, 1996-2001. Active in the State Planning Board } \\
\text { during Kudumbshree's initiation period. }\end{array}$ \\
\hline Ms. Mridul Eapan & Member of State Planning Board, 2006-2011. Academic \\
\hline Mr. Sabir Hussain & $\begin{array}{l}\text { Assistant District Mission Coordinator, Pathanamthitta, 1998-2004. } \\
\text { Kerala State Backward Classes Development Corporation, } \\
\text { Pathanamthitta 2004-2006. }\end{array}$ \\
\hline Mr. Liby Johnson & $\begin{array}{l}\text { Kudumbashree Mission, Team Leader, Programme Officer, 2009- } \\
\text { 2013. Kudumbashree National Resource Organisation Operating } \\
\text { officer, 2013-16 }\end{array}$ \\
\hline
\end{tabular}

Note: All interviews were conducted during 2014-16. The interviewees agreed to be cited by name.

a The first Executive Director, Mr. James Verghese, only served briefly in 1998. 